\title{
Supplemental Nutrition Drinks: Do I Need Them?'1
}

\author{
Claire Marie Fassett, Nancy J. Gal, and Wendy J. Dahl²
}

Optimum nutrition promotes good health at all ages. However, many older adults, especially those with poor health, are at risk for malnutrition (van der Pols-Vijlbrief et al. 2014). Older adults may experience a loss of appetite, which can reduce the amount and type of food they eat. This can lead to weight loss and frailty. Loss of appetite is linked to an increased risk of malnutrition in older adults (van der Pols-Vijlbrief et al. 2014). Specifically, they may not eat enough foods containing protein. Protein is critical for maintaining muscle, bone, and immune system health and strength (Wolfe, Miller, and Miller 2008).

Supplemental nutrition drinks are often used in hospitals and adult care homes to help nourish those who may be eating poorly and have lost weight due to illness or lack of appetite. More recently, nutrition drinks have become available for purchase by consumers. Examples of common supplemental nutrition drinks or shakes are Ensure ${ }^{\oplus}$ and Boost ${ }^{\oplus}$. This publication explores the question that many older adults ask: "Do I need supplemental nutrition drinks?”

\section{What are supplemental nutrition drinks?}

Beverages are intended to satisfy thirst, while nutrition drinks are meant to increase or supplement calories and nutrients. Supplemental nutrition drinks contain carbohydrates, fats, protein, and added vitamins and minerals. Some may also contain fiber. Supplemental drinks are designed to provide extra calories, protein, and other nutrients that are lacking when food intake is inadequate.

Supplemental nutrition drinks are promoted as a meal replacement or to increase overall calorie and nutrient intake. Supplemental nutrition drinks may be a beneficial addition to the diet of individuals with a poor appetite. Because regular meals often have more calories than one serving of a supplemental nutrition drink, it is best to use the drink between meals rather than as a meal replacement. Replacing one or more regular meals with a supplemental nutrition drink may not provide adequate calories to meet daily needs. While nutrition drinks are recommended to improve an inadequate diet, some consumers choose these drinks in addition to an already adequate diet. This may lead to consuming more calories than needed, resulting in unwanted weight gain.

\section{Types of Supplemental Nutrition Drinks}

There are a variety of supplemental nutrition drinks available to consumers. Nutrition drink formulations may be high in calories and protein or lower in carbohydrates. For example, there are nutrition drinks formulated for people with diabetes. These drink contain less carbohydrates than other nutrition drinks and may contain a type of carbohydrate that helps manage blood glucose levels by preventing glucose spikes. Some supplemental nutrition drinks are high in protein and are recommended for maintaining and

1. This document is FSHN18-12, one of a series of the Food Science and Human Nutrition Department, UF/IFAS Extension. Original publication date August 2018. Visit the EDIS website at http://edis.ifas.ufl.edu.

2. Claire Marie Fassett, MS-DI student, Department of Food Science and Human Nutrition, UF/IFAS Extension, Gainesville, FL 32611; Nancy J. Gal, Extension agent IV, UF/IFAS Extension Marion County, Ocala, FL 34470; and Wendy J. Dahl, associate professor, Department of Food Science and Human Nutrition, UF/IFAS Extension, Gainesville, FL 32611.

The Institute of Food and Agricultural Sciences (IFAS) is an Equal Opportunity Institution authorized to provide research, educational information and other services

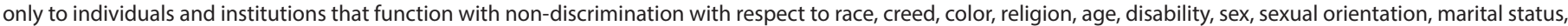

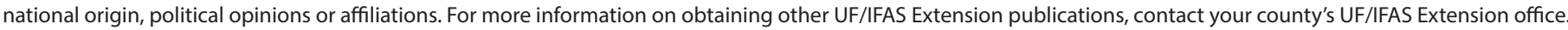
U.S. Department of Agriculture, UF/IFAS Extension Service, University of Florida, IFAS, Florida A \& M University Cooperative Extension Program, and Boards of County Commissioners Cooperating. Nick T. Place, dean for UF/IFAS Extension. 
rebuilding muscle after weight loss. Nutrition drinks high in calories are intended to prevent weight loss or promote weight gain in individuals who are underweight.

While supplemental nutrition drinks are fortified to help meet recommended intakes for vitamins and minerals, they may not fulfill all your dietary needs. Many whole foods also contain these same nutrients and may have other benefits, such as high fiber content. Fiber is important for proper gastrointestinal function and general wellness, but is relatively low or missing in most supplemental drinks.

One disadvantage of many supplemental nutrition drinks is their sugar content. Sugar is added by the manufacturers to improve taste. However, some nutrition drinks contain as much as 4 teaspoons of sugar in a 1 cup serving (see Table 1). The current Dietary Guidelines for Americans recommends limiting added sugars to promote good health (USDHHS and USDA 2015). Ingredients on food labels are listed in descending order by weight, and sugar is often one of the first ingredients listed on supplemental nutrition drink labels.

Table 1 lists some common supplemental nutrition drinks and beverages and their respective calorie, fat, protein, carbohydrate, and sugar contents. Protein and calorie contents of supplemental drinks are not much different than flavored cow's milk. However, the content of many of the vitamins and minerals may be higher in supplemental drinks compared to milk as they are added. Most supplemental drinks do not contain lactose, a naturally occurring sugar present in milk, making them suitable for those with lactose intolerance.

\section{Summary}

Supplemental drinks are best used to help older adults meet their daily nutritional needs by providing calories and nutrients not consumed from food. It is important to check with your health care professional first to see if including these drinks in your diet is appropriate. A registered dietitian nutritionist (RDN) can help you determine if you are meeting all your daily nutrient recommendations through food and if a supplemental drink is right for you.

\section{References}

USDHHS and USDA. 2015. "2015-2020 Dietary

Guidelines for Americans. 8th Edition.” http://health.gov/

dietaryguidelines/2015/guidelines/

van der Pols-Vijlbrief, R., H. A. Wijnhoven, L. A. Schaap, C. B. Terwee, and M. Visser. 2014. "Determinants of protein-energy malnutrition in community-dwelling older adults: a systematic review of observational studies." Ageing Res Rev. 18: 112-31. doi: 10.1016/j.arr.2014.09.001

Wolfe, R. R., S. L. Miller, and K. B. Miller. 2008. "Optimal protein intake in the elderly." Clin Nutr. 27(5): 675-84. doi: 10.1016/j.clnu.2008.06.008 
Table 1. A comparison of nutrient content of supplemental drinks and milks.

\begin{tabular}{|c|c|c|c|c|c|c|}
\hline ( 1 cup $=8$ fl oz) & $\begin{array}{l}\text { Energy } \\
\text { (calories) }\end{array}$ & $\begin{array}{l}\text { Fat } \\
\text { (g) }\end{array}$ & $\begin{array}{l}\text { Protein } \\
\text { (g) }\end{array}$ & $\begin{array}{l}\text { Carbohydrates } \\
\text { (g) }\end{array}$ & $\begin{array}{l}\text { Sugar* } \\
\text { (g) }\end{array}$ & $\begin{array}{l}\text { Fiber } \\
\text { (g) }\end{array}$ \\
\hline Boost $^{\oplus}$ & 240 & 4 & 10 & 41 & 15 (15 added) & 3 \\
\hline Ensure ${ }^{\circledast}$ & 220 & 6 & 9 & 33 & 15 (15 added) & 1 \\
\hline Glucerna $^{\circledR}$ & 180 & 9 & 10 & 16 & 4 (4 added) & 3 \\
\hline Milk & 149 & 8 & 8 & 12 & 12 (0 added) & 0 \\
\hline Chocolate Milk & 208 & 8 & 8 & 26 & 24 (12 added) & 2 \\
\hline Vanilla Soymilk & 100 & 3.5 & 6 & 10 & 7 (7 added) & 1 \\
\hline
\end{tabular}

